\title{
$\sqrt{ }$ Liberalism in South Africa 1948-1963
}

\section{Janet Robertson}

Since the Second World War a minority of South Africans-white as well as blackhas actively sought to extend equal rights to non-whites within the parliamentary system. This book describes what happened to liberals working within such groups as the African National Congress, the United Party, the Liberal Party, and the Progressive Party, and tells the story of the dismantling of the liberal state and the failure of the liberal ideal in South Africa. $£ 2.25$

Oxford Studies in African Affairs

\section{$\checkmark$ British Policy Towards West Africa}

\section{Select Documents 1875-1914 with \\ Statistical Appendices 1800-1914 \\ C. W. Newbury}

This volume continues the documentation of British relations with West Africa from the period of the Ashanti war to amalgamation of Nigeria. It includes sections on the response of African societies to British investment and control, imperial expansion into the interior, jurisdiction and administrative consolidation, the formation of the West African Frontier Force, and economic development. 4 maps $£ 4.50$

\section{$\checkmark$ African Traders and Economic Development in Ghana}

\section{Peter C. Garlick}

Peter Garlick attempts to identify the problems of an important group of African businessmen in Ghana. He examines the structure of their businesses, and indicates the impediments to growth of African private business enterprise in a country eager for economic development. His study should interest all social scientists concerned with developmental change in Africa. 3 text figures $£ 2.25$

Oxford Studies in African Affairs

\section{$\checkmark$ Basic Documents on African Affairs}

\section{Edited by Ian Brownlie}

The subjects dealt with in this useful and handy collection of documents include African intergovernmental organizations, economic development, territorial problems, self-determination and racial discrimination in Southern Africa, and relations with non-African powers. $£ 4.50$ paper covers $£ 1.90$ 

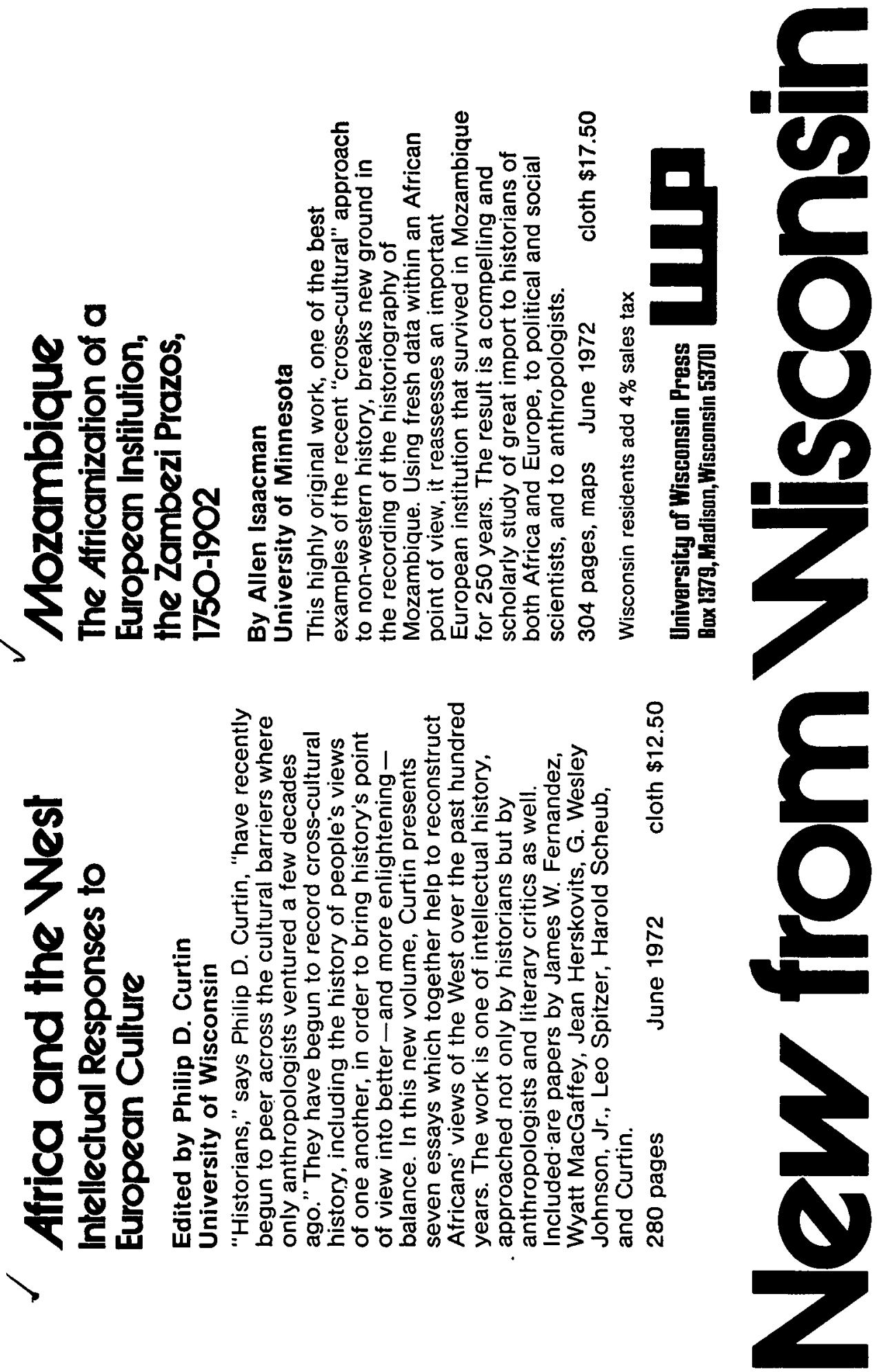

口 ๘ ※ \& క 品 ह

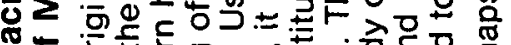

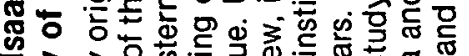

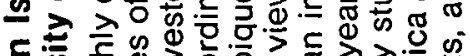

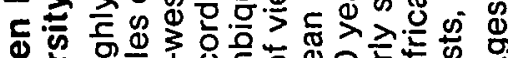

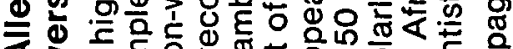

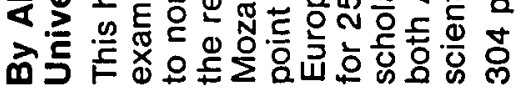

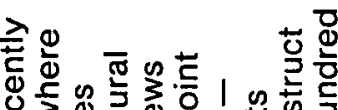

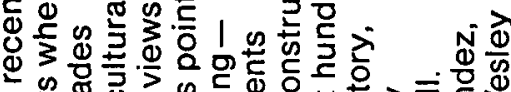
क⿺辶万亍

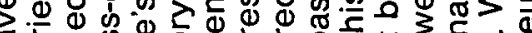
๙

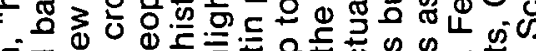

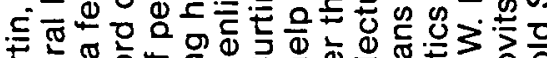

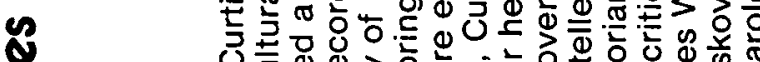

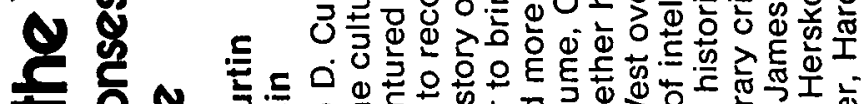

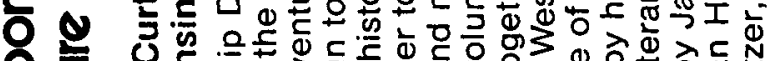

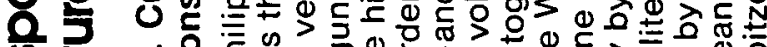

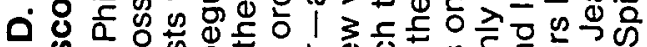
은 号

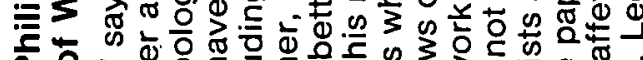

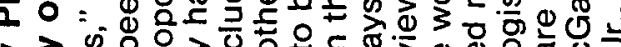
군

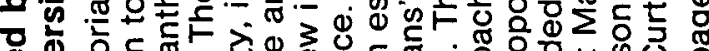

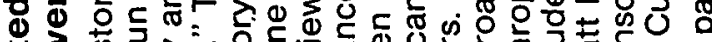

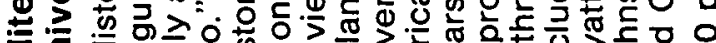

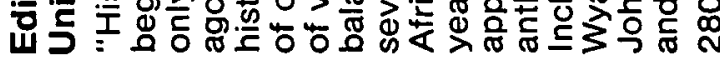
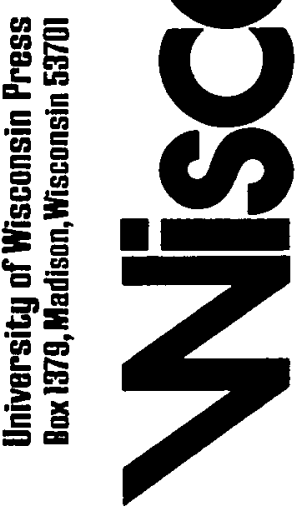


\title{
NEW FROM YALE
}

\author{
FRANCE AND BRITAIN IN AFRICA \\ Imperial Rivalry and Colonial Rule \\ edited by Prosser Gifford and William Roger Louis \\ with a Foreword by Harry R. Rudin
}

These essays provide a comprehensive analysis of competition and influence on the part of two major imperialist nations from the late nineteenth century to the struggle for Algerian independence in the 1960s. The authors have used the major archival materials of European and African repositories to present complementary assessments of French and British aspirations and tactics and African reactions and initiatives. This book is a companion volume to Britain and Germany in Africe Imperial Riva/ry and Colonial Rule, 1967 also edited by Messrs. Gifford and Louis.

$\$ 30.00$

\section{$\checkmark$ THE KING IN EVERY MAN}

\section{Evolutionary Trends in Onitsha lbo Society and Culture}

by Richard N. Henderson

Mr. Henderson explores ways of synthesizing two approaches to the study of pre-colonial African societies. First, in his investigation of the culture history of the Onitsha lbo he seeks to immerse the reader in the diverse, distinctive, and changing cultural configurations that define the day to day lives of the tribe members. Second, the book seeks to explain observed historical changes of a systemic nature. For this purpose the author employs general action systems theory and presents a multifectoral explanation of the evolutionary trends in an lbo society. This study provides the first examination of the social and cultural history of this region as well as an important portrait of a civilization in transition.

$\$ 25.00$

\section{WEST AFRICAN TRAVELS AND ADVENTURES}

\section{Two Autobiographical Narratives from Northern Nigeria}

\section{translated and annotated by Anthony Kirk-Greene and Paul Newman}

In 1855 an outstanding explorer of Africs, Heinrich Barth, took two Nigerian boys-Dorugu and Abbego-back to England with him. Dorugu dictated a memoir recounting his early life and travels with Barth. It is a sharp, often humorous commentany on northern Nigeria and records, as well, a young African's first look at European culture. Years later, Abbega's grandson Maimaina chronicled his adventures as political agent and interpreter with the British expeditionary force that established control over northern Nigeria at the turn of the century. These two narratives redress the conspicuous lack of autobiographical material in English from northern Nigeria. $\$ 10.00$

\section{THE LITERATURE OF ANCIENT EGYPT}

\section{An Anthology of Stories, Instructions, and Poetry} edited by William Kelly Simpson with translations by R. O. Faulkner, E. F. Wente, Jr., and W. K. Simpson

The first authoritative anthology of ancient Egyptian literary writings to appear in English since 1927 this volume will serve as an important adjunct to the study of Egyptian civilization. Many of the stories are vivid and offer keen reflections of the times, illuminating the cultural context of the Old Testament. These new translations reflect the work of generations of scholars from all over the world.

\section{Yale University Press New Haven and London}

\author{
in Canada: McGill-Queen's University Press
}




\section{Insurgency and counterinsurgency in Algeria}

By Alf Andrew Heggoy

Mr. Heggoy carefully analyzes the nationalist movement in Algeria, identifying the various insurgent groups and showing how their terrorist tactics forced the French into a new type of warfare, as well as into belated efforts at reform. This perceptive assessment of the Algerian experience sheds new light on anti-colonial struggles elsewhere.

352 pages

$\$ 10.00$

\section{Indiana University Press}

Bloomington, Indiana 47401 
Contributions to the fournal are welcomed. They may be submitted in either English or French and, except with the prior approval of the Editors, should not exceed about 6000 words. Two copies should be submitted, clearly typed with double spacing on quarto paper, and with a left-hand margin of at least $1 \frac{1}{2}$ in. $(4 \mathrm{~cm}$.). A summary of the contents of the article, not exceeding about 300 words in length, should be attached on a separate sheet. Footnotes, which should also be typed with double spacing, should be numbered consecutively throughout the article, and should include all bibliographical references; there should be no separate bibliography. First references should be complete, in standard form, so as to permit unequivocal identification of the book or article in question. Subsequent references should be by author's name and short title. Articles may be illustrated with line drawings and maps and, should the Editors agree that it is necessary, also with half-tone plates.

Galley proofs will be sent, if necessary by airmail, to each contributor (or his nominee) provided that the Editors have been given an address through which he can be reached without delay. Corrections should be kept to the minimum, and should be corrections, not new material. If they are to be incorporated in the master proof corrected by the Editors, it is important that the contributor should return the galleys, by airmail if necessary, to the Editor named when they are sent out (and not to the Cambridge University Press), within ten days of his receipt of them.

Contributors of articles and review articles receive 25 free separates. Additional separates may be obtained at reasonable cost, provided that they are ordered before publication on the special form sent out with the galley proofs.

All contributions and books for review should be addressed to The Editors, The Journal of African History, School of Oriental and African Studies, University of London, London, W.C.I. 


\section{CONTENTS}

page

I The accuracy of radiocarbon dates

By Haroln Barker (British Museum)

II Linguistic evidence regarding Bantu origins

By JosepH H. Greenberg (Stanford University)

177

18i)

III The growth of trade among the Igbo before I 800

By David NorthruP (University of California, Los Angeless) 217

IV The dimension of the Dutch slave trade from Western

Africa

By Johannes Postma (Mankato State College)

$\mathrm{V}$ Witchcraft accusations and economic tension in pre-colonial Old Calabar

By A. J. H. Latham (University College, Swansea)

VI Tripoli and the war with the U.S.A., I $80 \mathrm{I}-5$

By Kola Folayan (University of Ife)

VII The Maasai Warriors; pattern maintenance and violence in colonial Kenya

By Robert L. 'Tignor (Princeton University)

VIII Colonial and Settler pressures and the African move to the politics of representation and union in Nyasaland By Roger TANgri (Fourah Bay College, University of Sierra Leone)

IX Sir Philip Mitchell and 'Protected Rule' in Buganda By H. F. Morris (School of Oriental \& African Studies, University of London)

BOOKS REVIEWED

Olduvai Gorge : excavations in Beds I and II, I960-63. By M. D. Leakey (BriAn M. FAGAN), 325; Southern Nilotic History. By Christopher Ehret (A. N. TuCkBR and J. E. LAMPHEAR), 326; The Azande: history and political institutions. By E. E. Evans-Pritchard (Pierre Kalck), 329; Povver and Diplomacy in Northern Nigeria, 1804-1906; the Sokoto Caliphate and its enemies. By R. A. Adelęye (HumphreY J. Fisher), 332 ; Indiaps in Africa: a socio-economic study. By H. P. Chattopadhyaya (B. PACHaI), 335; Colonial life and political development in Tanzania: the case of the Makonde. By J. (Gus Liebenow (P. M. REDmond), 337; The Nigerian Military: a sociological analysis of authority and revolt, 1960-67. By Robin Luckhan (William Gutteridge), 339; The Sudan: a Southern vieupoint. By Oliver Albino (Robert O. Collins), 340; The Bulletin of A.R.S.T.O.M. in 1969 and 1970 (Roger Anstey), 342; Councils in Action. Edited by A. Richards and A. Kuper (R. Споок), 343.

\section{Shorter Notices}

The political development of Yoruba Kingdoms. By P. C. Lloyd (R. C. C. LAw), 344; Diaire Congolais (I690-I70I) de Fra Luca da Caltanisetta, trans. by François Bontinck (ANNE WiLson), 345; The Lutheran Church on the coast of Tanzania, 1887-1914. By S. von Sicard (MARCIA WrIGHT), 346; Towards Economic Independence: papers on the nationalization of the copper industry in Zambia. By M. L. O. Faber and J. G. Potter (P. E. SLinN), 347.

\section{Communications}

The Chronology of Bono-Manso. By Eva L. R. Mererowitz with a reply by Colin Flight, 348; An aftermath of the slave trade. By J. U. J. Asifgin, 350. 